\title{
TESE
}

\section{Desaparecidos civis: conflitos familiares, institucionais e segurança pública}

Dijaci David de Oliveira

Curso: Doutorado em Sociologia

Data da defesa: 10 de setembro de 2007

Orientadora: $\operatorname{Prof}^{\mathrm{a}} \mathrm{Dr}^{\mathrm{a}}$ Lourdes Maria Bandeira

\section{Resumo}

Nesta tese desenvolveu-se uma análise sobre o fenômeno dos desaparecidos civis, indivíduos que cotidianamente desaparecem sem que se tenha qualquer informação sobre seu paradeiro. Partiuse da hipótese de que o fenômeno é fruto de uma teia de relações que envolvem desde a microescala da família - e o seu desafio em lidar com os conflitos intergeracionais - até a macroescala do Estado - e a sua incapacidade para promover uma política de segurança eficaz.

Para realizar este trabalho, foi necessária uma discussão sistemática sobre o conceito de desaparecido civil, sendo constatadas diversas dificuldades teórico-metodológicas para a abordagem do problema. Os dados coletados no campo foram de grande valia para esclarecer a questão. Ao longo da pesquisa foram realizadas 57 entrevistas semi-estruturadas sobre a percepção dos desaparecimentos pelos familiares, gestores e delegados.

A análise dos dados indica que o fenômeno dos desaparecidos civis possui um pilar nas relações de gênero e outro nas relações geracionais. Sobre estes dois pilares estão presentes as relações familiares hierárquicas da sociedade patriarcal. Por fim, a 
pesquisa conclui pela necessária transformação da questão dos desaparecimentos em um problema de segurança pública, com a criação de programas de prevenção, de busca e de retorno.

Palavras-chaves: desaparecidos civis, segurança pública, família, gênero, geração.

\section{Rádio comunitária, espaço público e democracia: estudos de casos na França e no Brasil}

Sayonara de Amorim Gonçalves Leal

Curso: Doutorado em Sociologia

Data da defesa: 14 de setembro de 2007

Orientadora: $\operatorname{Prof}^{\mathrm{a}} \mathrm{Dr}^{\mathrm{a}}$ Maria Francisca Pinheiro Coelho

\section{Resumo}

Este trabalho contempla o estudo do papel das rádios associativas francesas e das rádios comunitárias brasileiras como espaços públicos que abrigam diferentes lógicas de ação e onde se manifestam discursos de caráter político, cultural e social, em vários gêneros, informativo e opinativo, em especial, este último. Tais espaços são permeados por ações comunicativas e instrumentais, nos termos defendidos por Habermas, manifestas nas tensões e aproximações entre espaço público e espaço comum.

Com base em estudos de casos dessas mídias, constata-se a dinâmica desses espaços e as lógicas de ação que operam em seu 